\title{
Patenting and licensing by Spanish firms: available survey evidence
}

\author{
Catalina Martinez ${ }^{*}$ \\ CSIC-IPP, Instituto de Políticas y Bienes Públicos, Consejo Superior de Investigaciones \\ Científicas, Albasanz, 26-28, Madrid-28037, Spain \\ catalina.martinez@csic.es \\ Gerardo Penas \\ OEPM, Oficina Española de Patentes y Marcas, Castellana, 75, Madrid-28046, Spain \\ gerardo.penas@oepm.es
}

This is a pre-copy-editing, author-produced PDF of an article accepted for publication in World Patent Information following peer review. The definitive publisher-authenticated version [Patenting and licensing by Spanish firms: available survey evidence, World Patent Information, 2013] is available online at: http://dx.doi.org/10.1016/j.wpi.2013.06.003

\begin{abstract}
This paper presents the results of the OEPM/OECD survey on the economic and financial uses of patents carried out in 2008 among Spanish business applicants of OEPM patents. It also summarises evidence from previous surveys. All available information indicates that only a few Spanish firms holding patents license them out. Results from the OEPM/OECD survey also reveal that obtaining public support is the first financial use of patents for Spanish firms. Responses to the same OECD questionnaire by EPO patent applicants from several European countries are quite different: licensing out is an extended practice among EPO patent holders from different countries, including Spain, and convincing venture capitalists and private investors are their two most important financial uses of patents. In our view this suggests that there are significant differences across European countries as regards the development of national technology markets and results from international surveys are driven by responses from the largest and more developed countries. The drivers and actors in markets for patents that only protect inventions nationally may be quite distinct from those in markets for patents that protect inventions regionally, such as EPO patents within Europe.
\end{abstract}

Keywords: Spain; Patents; Licensing; Survey; OEPM; OECD; EPO.

\footnotetext{
* Corresponding author.
} 


\section{Introduction}

One of the most recurrent recommendations of science and technology policies is to foster the diffusion and transfer of the technology. However, policy makers often have little or only partial empirical evidence to rely on when formulating these recommendations, especially as regards the degree of development of technology markets in their countries.

The need to have detailed and reliable data on Spanish business technology transfer is a long standing demand. Technology transfer agreements are private contracts and parties involved are not obliged to disclose the nature of their activities. Some commercial databases provide information from press releases, rumours and business reports, but they are limited to publicized deals and have traditionally relied mainly on English sources, reducing the coverage for operations in other languages, namely Spanish. Some information on cross-border technology transfers can be obtained from official sources, such as the Balance of Payments, but this only offers a partial view which is often difficult to reconcile with domestic statistics on science and technology [1]. A few years ago, another relevant source for official information on cross-border business technology transfer in Spain was the national Registry of Technology Transfer Contracts [2], but the obligation to register technology contracts with non-residents was abolished when Spain joined the European Community in 1986. $^{1}$

One way to overcome the lack of data from official sources consists in looking at technologies protected by patents and the commercial uses of those patents. Despite their limitations, such as different patenting propensities across technologies and different degrees of maturity of patent systems across countries, patents are a visible means of protecting inventions that is increasingly used to monitor patterns of technology generation and protection within and across countries. Again, however, the private nature of patent licensing and transfer contracts makes it very difficult to obtain information about technology transfer associated with patent deals. Many patent offices keep national registers of patent licensing and changes of ownership, but not all firms entering into licensing agreements make use of them. As a result, surveys have become a common way to overcome the lack of official statistics on business technology transfer in general, and on patent licensing and sales in particular.

The main objective of this paper is to review available evidence from scattered surveys that include questions about business patent licensing in Spain, including responses to the OECD questionnaire on the economic and financial uses of patents [3], distributed with the support of the Spanish Patent and Trademark Office (OEPM) among Spanish companies in 2008 (the OEPM/OECD survey). Results of the latter are compared with main findings from responses to the same OECD questionnaire from European business applicants to the European Patent Office (EPO), from different European countries including Spain (hereafter the EPO/OECD survey), as described in

\footnotetext{
${ }^{1}$ Real Decreto 1750/1987, 18 December, on the liberalisation of technology transfer and foreign technical assistance to Spanish firms.
} 
Zuniga and Guellec [3]. The target population of the OEPM/OECD survey, whose results we present for the first time here, were Spanish business applicants of OEPM patents, whereas the target population of the EPO/OECD survey were business applicants of EPO patents from different countries, including Spain. They address different types of applicants and hence their responses may reflect different approaches to patents and their use.

The paper is organized as follows. Section 2 presents available evidence from other Spanish surveys. Section 3 starts by briefly summarizing the results from the EPO/OECD survey and then describes the implementation and main results of the OEPM/OECD survey. Section 4 concludes.

\section{Background}

Official R\&D statistics from the Spanish National Institute of Statistics (Instituto Nacional de Estadística, INE) ${ }^{2}$ indicate that Spanish firms invest less in R\&D than their European counterparts. Spanish public effort in R\&D spending generally exceeds private effort. $^{3}$ In 2008, the year when the OECD survey on patent uses was carried out in Spain, 1.35\% of GDP was spent in R\&D (14 701 million euros) a figure below the European Union average of $1.90 \%$ and far from the $3 \%$ objective set up in Lisbon by the European Council for the year 2010. The contribution of Spanish firms to total R\&D spending was less than in other countries: $55 \%$ against $64 \%$ for the EU average.

According to the Technological Innovation Survey, administered by INE ${ }^{4}$, about 30000 firms, $16 \%$ of the total, had some innovative activity in Spain in 2007-2009. Among them, 37\% did R\&D, precisely 11200 firms, but only 7694 did R\&D continuously. The figures for the previous period (2006-2008) are slightly higher, 36183 firms had some innovative activity, 12997 did R\&D and 8562 did R\&D continuously. We are then talking about a relatively small number of firms: only about 8000 firms do R\&D continuously in Spain. Moreover, they are unevenly distributed across sectors, with a large concentration (more than $40 \%$ of firms doing R\&D) in pharmaceuticals, chemistry and IT products and services or aeronautical construction. As regards firm size, $28 \%$ of firms with more than 250 employees do $R \& D$, compared to only $6 \%$ with less than 250 . The Technological Innovation Survey also provides some (limited) information about the extent of markets for technology: about 58\% of innovative firms declare to have acquired machinery hardware and software in the 2004-2009 surveys, but only 5\% acquired other external knowledge.

The OEPM receives more than 3100 national applications per year and publishes about 2000 eighteen months after the filing date, the rest are withdrawn before publication. $90 \%$ of these national published patent filings are filed by Spanish applicants, who can later extend their applications for patent protection to the EPO

\footnotetext{
${ }^{2}$ Encuesta sobre actividades de I+D, http://www.ine.es/inebmenu/mnu_imasd.htm

${ }^{3}$ The transfer of technology produced by Spanish universities and public research organisations is also an area of major policy interest, but it touches upon very different issues and also covering them is beyond the scope of the present paper.

${ }^{4}$ Encuesta sobre innovación en las empresas 2009, http://www.ine.es/inebmenu/mnu_imasd.htm
} 
and other countries or not. In contrast, $84 \%$ of all patents with effect in Spain correspond to EPO patents validated in Spain, 99\% of which belong to foreign firms [4].

Several one-off surveys have been performed in Spain in recent years, all of them with the support of the OEPM and with the aim to shed some light on the different motivations and obstacles faced by Spanish firms when seeking patent protection for their inventions. Results from all these surveys are consistent: Spanish firms give little importance to patent licensing. ${ }^{5}$

The first one, Hidalgo [6], presents the results of a survey of Spanish firms with EPO granted patents. It was carried out in 2001 with the objective to know more about patents as a source of information and instrument for technological surveillance. Among the 123 Spanish firms (63\% Small and Medium Enterprises, SMEs) who responded to the questionnaire, all of them owners of EPO patents filed between 1988 and 1998, 70\% considered the defense of industrial property to be very important and more than half $(53 \%)$ considered patent licensing to be of low importance.

The second one, Arce et al [7], presents the results of a survey of Spanish firms in the sectors that concentrate most of the R\&D activity. It was done with the aim to identify their eventual training and assistance needs in the area of intellectual property rights (IPRs). Among the 113 firms who responded to the questionnaire, the defense of industrial property was considered very important by the largest number of firms (38\%), whereas licensing patents was considered to be very important only for $8 \%$. Furthermore, $27 \%$ considered licensing of low importance, compared to only $2 \%$ who considered defense of industrial property of low importance. ${ }^{6}$ When asked about incentives needed to increase their interest in industrial property, most of them opted for tax incentives (46\%).

The third one, Hidalgo [8], presents the results of a survey to firms in sectors with $R \& D$ activity. It was done with the aim to identify success factors for the development of technological cooperation. According to 250 interviews with Spanish firms (88\% of them SMEs), other services, essays and trials is by far the first technology transfer mechanism for firms (80\%), followed by patent licenses $(48 \%)$ and joint projects with scientific institutions (43\%).

Finally, Hidalgo [9] presents the results of a survey done with the aim to better understand commercialization patterns of Spanish patents granted between 1996 and 2006, where commercial use of patents comprises the commercialization of the

\footnotetext{
${ }^{5}$ Another European survey that reports some information on patent uses in Spain is the so-called PatVal-EU survey of European patent inventors, conducted in 2003, but it is not included in this review because it was addressed to inventors, not patent holders and its aim was to estimate the value of EPO patents with inventors from different countries [5].

${ }^{6}$ Firms were asked to rank between 1 and 3 the importance of their own patents for their business ( 1 : low importance, 3: very important) where they had to choose among six possible responses: i) defense of industrial property; ii) more capacity to negotiate loans; iii) negotiations with other firms; iv) technology export; v) patent licensing; and vi) formalization of knowledge ([7], p.199).
} 
patented invention by patent holders and it is thus a much broader concept than patent licensing. Implemented in 2007, results related to firm responses were based on 72 replies from companies ( $42 \%$ SMEs). To the question about uses of patents, respondents could choose among internal use, commercial use, development of other patents, blocking and no use. The questionnaire did not include a specific question about patent licensing. The two most frequent uses of large firms were internal use (58\%) and commercial use (42\%), followed by development of other patents (28\%), blocking competitors (7\%) and no use (5\%). Internal use was also the use most frequently reported by SMEs (71\%), but the second was development of other patents (26\%). Commercial use was the third use for SMEs (23\%), followed by no use $(16 \%)$ and blocking was the last one $(3 \%)$.

More information about the objectives and samples surveyed in all the OEPM surveys mentioned, as well as on the OEPM/OECD survey described below, can be found in Table $\mathbf{A} 1$ in the Annex.

\section{The OECD survey on the economic and financial uses of patents}

The main objective of the OECD questionnaire on the economic and financial uses of patents was to obtain information about the market for patented technology in OECD countries and the method chosen was to ask patent holders about their licensing out activities. Detailed results and a description of the methodology of the 2007 implementations of the OECD survey among patent applicants to the EPO and the Japan Patent Office (JPO) are described in Zuniga and Guellec [3]. ${ }^{7}$ Results suggest that there is growing licensing activity in Europe, which indicates increased dynamism of European technology markets, despite their late emergence with respect to United States or Japan. The main (average) results of the EPO/OECD survey are as follows, as described in [3]:

- A significant share of European firms holding EPO patents license them out: $35 \%$ of European firms declare having licensed out patents, but much of the transactions are between affiliated companies.

- Licensing out to independent entities (non-affiliated) is declared by $20 \%$ of European companies. The highest proportion of firms licensing out to independent companies in Europe is found in the United Kingdom, followed by the Nordic countries.

- The relationship between company size and share of licensing to independent entities is U-shaped: small and large companies are more often involved in licensing out than medium-sized companies.

- The first motivation to license to third parties for European is, by far, earning revenue, the second one is entering into cross licensing deals.

- As regards willingness to license, $24 \%$ of European patenting firms have patents that they were willing to, but could not, license-out.

\footnotetext{
${ }^{7}$ For other relevant references on patent licensing surveys in Japan see Motohashi [10] and Kani and Motohashi [11].
} 
- The main hampering factor for licensing-out, by far, is the difficulty of finding partners: $25 \%$ of European companies consider it as a very important factor.

- Convincing venture capitalists and obtaining funding from private investors are the two most important financial uses of patents, ranked as very important by $11 \%$ and $13 \%$ of European respondents, respectively. This rating is much higher for young firms ( $31 \%$ and $40 \%$ respectively). In contrast, obtaining public subsidies is considered to be very important by only $8 \%$ of all firms.

The target population for the EPO/OECD survey was made of applicants who had filed an EPO patent application in 2006. The questionnaire was sent to applicants from three combined samples: largest applicants (more than 2 filings in 2006); random sample; and smallest applicants (less than 2 filings in 2006) [3]. Hence, given that the sampling procedure depends on patent filings and the number of EPO patent applications coming from Spain is relatively low, the number of responses from Spanish firms to the EPO/OECD questionnaire is also low. Average responses from European firms are mainly driven by the leading countries: Germany, France, United Kingdom, Italy, Netherlands and Switzerland [12, p.15].

\subsection{Implementation in Spain}

In the OEPM/OECD survey, the OECD questionnaire on the economic and financial uses of patents was distributed to all Spanish firms with a national patent application to the OEPM published in 2007. This target population represents the large majority of Spanish firms who filed a national patent in 2005-2006, since according to the Spanish Patent Law of 1986, all inventions originated in Spain have to the patented first at the OEPM before seeking international protection (Article 122, Spanish Patent Law 1986) and patent applications are published 18 months after the filing date.

Between August and November 2008, a Spanish version of the OECD questionnaire was sent to all firms with an address in Spain having an OEPM patent application published in 2007. Thus, applicants of Patent Cooperation Treaty (PCT) patent applications filed at the OEPM, foreign applicants of OEPM patents as well as individual inventors, foundations, technology centers, private non-for-profit institutions, universities and public research centers were excluded. ${ }^{8}$

A total of 679 questionnaires were sent (target population), of which 27 were returned because of change of address, cease of activities or irrelevance of the survey for the activity of the firm. In the end, 93 valid responses were received, what

\footnotetext{
${ }^{8}$ The first mailing was done in August 2008. The communication was done by email when an email address was available for the relevant contact person, and with the post to the rest. All correspondence was addressed to the IPR or R\&D manager of the firm, when the contact was available, or to the CEO when not. Between the first and the second mailing, many questionnaires were returned due to mistakes in the postal address or because the company had changed address and was unknown at destination. During October 2008, many of the addresses in the OEPM database were updated searching for information on the companies' websites and other Internet sources, including databases on corporate information and in November 2008 the questionnaire was sent to applicants with these updated addresses in a second round of mailings.
} 
amounts to a response rate of $14 \%$. The 679 firms in the target population had altogether filed a total of 950 national patent applications published by OEPM in 2007, ${ }^{9}$ whereas the 93 responding firms had 199 (21\%).

Large applicants are relatively better represented in the final sample of responding firms than small ones. Among the responding firms we find $11 \%$ of the firms in the target population with only one application and $25 \%$ of those with two or more filings.

The distribution by technological areas is quite similar for the patents filed by the firms in the target population and the patents filed by the responding firms, with the largest share being in mechanical engineering fields (Figure 1).

\section{***FIGURE 1 AROUND HERE***}

A comparison of the geographic distribution of firms shows that those in the target population are present in all 17 Spanish regions (Eurostat Nomenclature of Units for Territorial Statistics, NUTS, 2 level $)^{10}$ whereas those responding to the questionnaire concentrate in 14 of them. The Basque country and Navarra are relatively better represented in the responses, while Valencia is relatively less well represented in the responses than in the target population. Looking at the distribution by province (NUTS, 3 level), Barcelona and Madrid have the largest number of firms in the population. Barcelona also has the highest concentration of responding firms, but Madrid takes the fourth position, after Guipuzcoa and Navarra (Figure 2).

\section{***FIGURE 2 AROUND HERE***}

In sum, responding firms seem to be representative of the target population in terms of geographical distribution as well as in terms of number and technological breakdown of their OEPM patent applications.

\subsection{Results from Spain}

This section presents the results of the OEPM/OECD survey, as well as information on sector of activity, firm size, founding year and affiliation to a business group of responding firms, as declared in their responses to the questionnaire. ${ }^{11}$

- As regards the sector distribution of responding firms, $47 \%$ of the responding firms concentrate in three sectors of activity: i) construction of machinery and mechanical equipment (15\%); ii) electrical, electronic and optical material and equipment material (15\%); and iii) business technical services (17\%) (Table $\mathbf{A} 2$ in the Annex).

\footnotetext{
9 The rest of OEPM applications published in 2007, excluding PCT ones, up to total of 2 137, correspond to individual inventors, universities, public research centers, technology centers, firms with unknown address, and other institutions with foreign addresses.

${ }^{10}$ http://epp.eurostat.ec.europa.eu/portal/page/portal/nuts_nomenclature/introduction

${ }^{11}$ The results presented in this section correspond in each case to the simple count of responses.
} 
- As regards firm size, the smallest responding firm has only one employee and the largest one 12 000, but the majority of them have less than 100 (58\%). The average size of the responding firms is 496 employees, which indicates, together with a high standard deviation of 1517.69 , that there is a large diversity of sizes among the responding firms.

- As regards age, most of the responding firms were created before 1985 (53\%). The oldest firm was created at the beginning of the 20th century, in 1911, the youngest one in 2007 and the average year of creation is 1981 (standard deviation 20.40). Finally, on affiliation to a business group, $56 \%$ of the responding firms are part of the business group, $42 \%$ to a national group and $14 \%$ foreign.

The survey includes questions on three themes: i) the importance of patents and motivations to patent; ii) technology transfer and patent licensing; and iii) other financial and commercial uses of patents. This is also how we have structured the presentation of the survey results below. ${ }^{12}$

\subsubsection{Importance of patents and motivations to patent}

In the first question of the questionnaire, firms were asked about the proportion of inventions patented in 2007, to capture a measure of the propensity to patent of the responding firms. 79 firms replied to this question and amongst them, $11 \%$ said they had not patented in the previous year any of their patentable inventions, $25 \%$ said they had patented less than $50 \%$ and $63 \%$ more than $50 \%$.

The second question enquired about changes between 2004 and 2007: 43\% said they had augmented the proportion of patented inventions, and $55 \%$ said they had not seen any change $(\mathrm{N}=92)$. Logically enough, the large majority $(74 \%)$ of the firms who report an increase in the importance of patents are amongst the ones who had increased their patent filings.

As regards the perception of responding firms about the importance of patents as a means to appropriate returns from innovation, $62 \%$ considered patents as a very important protection means, above industrial secrets, complexity of design in products or processes, and lead time advantage, which were considered very important only by $39 \%, 29 \%$ and $28 \%$ of the responding firms, respectively (Table 1 ). Again, it is not surprising to find that $83 \%$ of the firms who had declared that patents had gained importance in their business between 2004 and 2007, and 51\% of those who said that it had remained constant, are among the firms who also consider patents as a very important protection means.

\section{$* * *$ TABLE 1 AROUND HERE***}

Among the motivations to file patents, protection against imitation takes the first position, declared as being very important for $72 \%$ of the responding firms (Table 2 ). The rest of motives are far below in the ranking in terms of number of firms

\footnotetext{
${ }^{12}$ The Spanish questionnaire is available upon request. The original version of the OECD questionnaire (in English) can be found in [3].
} 
considering them as very important. The second most important motive is to avoid litigation (38\%), the third one preventing others from patenting (36\%), and the fourth one gaining bargaining power (30\%). Obtaining additional revenues from licenses and entering into cross licensing agreements are amongst the motives that receive the lowest consideration, together with obtaining external funding. In a mature technology market we would expect a greater importance of all these motives, so that this result already advances that the transfer of patented technology in not vital for the responding firms, and by extension, the market for technology in Spain is not sufficiently developed. Table $\mathbf{2}$ presents the distribution of responses for all motivations.

\section{$* * *$ TABLE 2 AROUND HERE***}

\subsubsection{Technology transfer and patent licensing}

As regards licensing, 69\% of the responding firms had not licensed out any of their patents, $18 \%$ had licensed less than $50 \%$ of their patents and $13 \%$ more than $50 \%$ $(\mathrm{N}=90)$. In sum, only 28 responding firms reported having licensed-out patents, the majority of them to firms belonging to the same company group $(59 \%, \mathrm{~N}=22)$ and to entities also located in Spain (58\%, $\mathrm{N}=24)$. Only $15 \%$ reported to have entered into cross licensing agreements $(\mathrm{N}=20)$. Such a poor licensing performance seems to be an established trend, given that for $80 \%$ of the responding firms both the revenues from licensing and the number of licenses granted had remained constant between 2004 and 2007.

Firms were also asked about the importance of patent licensing compared to licensing other IPRs. Only 32 firms declared having granted licenses for at least one type of IPRs (trademarks, know-how, copyright, utility model). Only four firms had granted licenses of other IPRs and not for patents, and the rest had granted licenses of more than one type of IPR, including patents. This indicates that patent licenses are usually accompanied by licenses of other types of IPRs, in a package. Firms give access to their patented inventions together with complementary assets, from commercial assets to exploit the patented products (trademarks), to tacit knowledge about the patented technology (know-how). Trademark licenses were the most popular, for $58 \%$ of the firms, followed by utility models for $55 \%$ and know-how for $47 \%$. Copyright was the least common, with only $19 \%$ of the responding firms reporting having granted copyright licenses in 2007 (Table 3).

\section{$* * *$ TABLE 3 AROUND HERE***}

When we consider all responding firms, including those who declared not having granted any license in the previous year, we find statistically significant differences in average licensing shares as regards company size, year of creation, affiliation to company group and sector of activity. First, firms with less than 100 employees licensed, on average, $20 \%$ of their patents, whereas those with more than 100 employees only license 4\%. Second, older firms (created before 1985) licensed $8 \%$ of their patents, whereas younger firms licensed $21 \%$. Third, firms that belong to a 
corporate group licensed $8 \%$ of their patents, whereas independent firms licensed $21 \%$. And, finally, service firms licensed only $4 \%$ of their patents, compared to $17 \%$ for manufacturing firms (Table 4). Thus, smaller, younger and independent firms are more likely to license out their patents. This result is consistent with previous studies ([3], [13]), but should be taken with caution given the small number of firms in the sample that license out their patents.

\section{***TABLE 4 AROUND HERE***}

The survey also enquires about the motivations to license patents. Consistently with the EPO/OECD survey, obtaining additional revenues takes the first position. $29 \%$ of firms declared having granted more than $50 \%$ of their licenses for that motive. The second most important motive is patent infringement by third parties, $21 \%$ of the firms reports that as the cause for more than $50 \%$ of their licenses (Table 5). Entering cross-licensing agreements is the motive with the lowest number of responses: $92 \%$ of responding firms said that cross-licensing was not a motive to grant licenses. These results contrast with those of the EPO/OECD survey where infringement was the third motive, after cross-licensing. This difference regarding cross-licensing might be an indication of the kind of technologies licensed out by the sampled firms in both surveys. Cross-licensing is more commonly used in fields with complex technologies, such as electronics. It might also be due to the insufficient development of technology markets in Spain, compared to other European countries, which implies that Spanish firms do not even consider cross-licensing as an option.

\section{$* * *$ TABLE 5 AROUND HERE***}

The lack of interest to grant patent licenses for the majority of surveyed firms is clearly reflected in their response to the question on barriers to licensing. 65\% declare not having found any barrier simply because they never wanted to grant licenses of their patents, $26 \%$ found barriers to license for less than $50 \%$ of their patents and $9 \%$ for more than $50 \%(\mathrm{~N}=71)$.

Among the firms who had not granted any license, 30\% would have liked to license but could not $(\mathrm{N}=47)$, and among the firms who had granted licenses, $48 \%$ would have liked to grant more $(\mathrm{N}=23)$. All firms these firms, therefore, faced some barriers to transfer their technology through licensing out their patents to third parties.

To the question about types of obstacles, more than half of the responding firms declared that it had been difficult to find interested parties (52\%), consistently with the EPO/OECD survey. The second obstacle in importance being the complexity and cost involved in drafting and negotiating licensing contracts (considered as a barrier moderately important or important by $29 \%$ of the firms), and the third one was the insufficient development of the patented technology (important for $28 \%$ of the firms). The price offered was not considered a relevant obstacle by $54 \%$ of the firms (only $19 \%$ considered it as important), again consistently with the EPO/OECD survey (Table 6). 
Restricting the analysis to firms who would have liked but could not grant licenses of their patents, the difficulty in finding interested firms gains importance, considered as moderately important or very important by $87 \%$ of the responding firms. The price is still considered as not very relevant or of low importance by the majority of firms (66.7\%). On the other hand, there is division of opinions between firms who could not license about the complexity of drafting and negotiating contracts, as well as for the development of the technology. Chi-2 tests show that there are significant differences in the importance given to each of these barriers between licensing and non-licensing firms.

\subsubsection{Other financial and economic uses of patents}

In the last part of the questionnaire, firms were asked about the importance of their patents in other commercial or financial activities different from patent licensing. Surprisingly, obtaining public funding was the activity most often reported by responding firms. Patents were considered to be very little or not at all relevant for the large majority of firms as a means to obtain private funding from venture capital, private investors or the stock market and borrow money from the financial system through bank loans or securitisation. $80 \%$ of the responding firms consider that patents are relevant to obtain public support, whereas only $48 \%$ consider them relevant to negotiate loans; $49 \%$ to obtain funding from private investors; $45 \%$ from venture capital and only $27 \%$ from the stock market (Table 7 ).

\section{***TABLE 7 AROUND HERE***}

This is consistent with the fact that public R\&D effort exceeds private R\&D effort in Spain and indicates that Spanish firms tend to seek public support when they need funds to innovate, rather than private funding. This might be due to factors related both to the supply side (insufficient offer of private funds to innovative projects in Spain) and the demand side (innovative firms prefer public funds to develop their projects because they entail less risks, for example, if they are in the form of soft loans or subsidies).

Moreover, the characteristics of responding firms do not seem to be significantly related to their perception of patents as relevant or not for different financial uses. ${ }^{13}$ All responding firms, independently of their size, age, independence and sector of activity, believe that patents are relevant to obtain public funds.

In contrast, the age of the firm is significantly related to the importance of patents to obtain funds from private investors and negotiating loans. 59\% of the firms created after 1985 consider that patents are relevant to obtain funds from private investors, where $63 \%$ of those created before 1985 considers that it is not relevant (Pearson Chi $2=3.827$; sig. asymp. two sided=0.050). Likewise, $60 \%$ of the firms created after 1985

\footnotetext{
${ }^{13}$ Where 'relevant' is the result of combining results from categories 'low importance', 'moderately important' and 'very important'.
} 
considered that patents were relevant for negotiating loans, compared to $65 \%$ of the firms created before 1985, which considered them as not relevant (Pearson Chi-2= 5.248; sig. asymp. bilateral $=0.022$ ). Younger firms rely more than older ones on private funds.

Belonging to a corporate group is related to obtaining venture capital. $55 \%$ of the firms who do not belong to a business group consider that patents are relevant to obtain venture capital, whereas $65 \%$ of those who belong to a business group consider that they are not relevant (Pearson Chi- $2=3.542$; sig. asymp. bilateral $=$ 0.060). This result is easy to understand as firms belonging to corporate groups can find capital within their own firm when they want to get involved in innovative projects, whereas independent firms need to get external funding, in this case, from venture capital.

Venture capital has a relatively short, but dynamic history in Spain, with foreign operators first entering the country only in 1986. It has also received strong political support in recent years. ${ }^{14}$ A new law was enacted at the end of 2005 to cut red tape and increase the flexibility of venture capital investments. Shortly after, the Spanish Ministry of Industry created a 'venture capital fund of funds' under the name of Proyecto Neotec Capital Riesgo, with the participation of a number of Spanish banks and large firms. It was specifically directed to encourage new technologically based firms with the aim to foster the development of a segment (technological venture capital) that was still disproportionately underdeveloped in Spain. ${ }^{15}$ By 2009 , venture capital investment as a percentage of GDP was lower in Spain than in many other European countries at $0.016 \%$ (of which only $34 \%$ was early stage), but still ahead of Italy at $0.004 \%[14]$.

The last question of the survey refers to the sale of patents, as an alternative to licensing for the transfer of technology. It relates to cases when the owner of the patent transfers the title of the patent, and all his rights, to a third party, so that the patent changes ownership. This option is even less used than licensing out by the Spanish firms surveyed. Only $10 \%$ of the responding firms declare having sold patents to third parties, approximately $7 \%$ report having sold less than $50 \%$ of their patents and the other $2 \%$ more than $50 \%(\mathrm{~N}=83)$.

\section{Conclusions}

All available evidence from surveys on patenting and licensing in Spain points at the low importance given by firms to earning revenues from licensing at the time of patenting and the low involvement of Spanish firms in patent licensing. The results of the OEPM/OECD survey administered to Spanish business applicants of OEPM patents, whose results we have presented in this paper, also confirm this view. This contrasts with the responses to the same $O E C D$ questionnaire from European companies holding EPO patents that responded in the EPO/OECD survey, for whom licensing is a widespread activity.

\footnotetext{
${ }^{14} \mathrm{http}: / /$ www.webcapitalriesgo.com

${ }^{15} \mathrm{http}: / /$ www.cdti.es/index.asp?MP $=7 \& M S=664 \& M N=4$
} 
It is important to put results from these two implementations of the OECD survey into perspective, however, and keep in mind the differences between their target populations. In the case of the OEPM/OECD survey, the target population is Spanish business applicants of OEPM patents. In the case of the EPO/OECD survey, it is business applicants of EPO patents from different countries, and given the sampling procedure, the countries that contribute most to the total number of applications are more represented than others. These leading countries are Germany, France, United Kingdom, Italy, Switzerland and Netherlands. Spain is amongst the laggards, and thus, not as well represented in the results.

Our findings show that markets for licensing, although have become a buzzword in most S\&T and innovation policy documents, differ greatly across countries and depend on the kind of actors and the types of technologies considered. As noted by previous studies, the European market for technology is fragmented and its inefficiencies hinder patent licensing [13]. Our results should also serve as a warning against the generalization of results from surveys to applicants of high value patent applications (EPO filings) that may be driven by responses from leading countries, to laggard countries characterized by the coexistence of two types of patent applicants, those who only patent nationally and those who also patent internationally. A task for further research would be to administer the same survey, at the same time and with the same sampling methodology, to these different types of patent applicants, distinguishing between them with the aim to compare responses from both groups.

There is need to better understand the incentives of different types of patent applicants to use and foster technology markets and how different policies can affect them. It is also important to take account of how all different factors determining the development of patent licensing markets may affect them, such as regulatory framework, technology specialization, industrial structure, and importance of other means to appropriate results from innovation across different fields. The steps taken at the European level to foster technology exchange and open innovation are giving fruits, as shown by the positive results obtained from the EPO/OECD survey.

Whereas technology and knowledge transmission are at the core of the Spanish Innovation Strategy [15] developed by the government for the coming years, the value of patents and technology transfer drivers in general seem to have been underestimated in it. This oversight could lead to focus efforts on objectives that will not give the pursued results. According to the available survey evidence, Spanish companies rely too much on public financing of R\&D as a motivation to patent. This may discourage private investment to support more ambitious and risky operations. Efficient measures to foster private investment and, at the same time, find the right balance between private and public investment are urgently needed. 


\section{ACKNOWLEDGEMENTS}

We are grateful to Pluvia Zuniga for her comments and support during the implementation of the OEPM/OECD survey. We also thank Dominique Guellec for his advice. Kenedy Alva and Jose Manuel Rojo provided assistance with the data, Esther Arias helped with the implementation of the survey and Pepa Montejo provided useful comments to the questionnaire. Catalina Martinez acknowledges support from Ministerio de Economía y Competitividad CSO2009-10845 and CSO2012-32844.

\section{REFERENCES}

[1] Sanchez, P., Vicens, J., 1991, Recent developments in the export of technology by Spanish companies, Science and Public Policy, 18, 5: 281-93.

[2] OECD, 1987, Innovation Policy in Spain, Organisation for Economic Cooperation and Development, Paris.

[3] Zuniga, P., Guellec, D., 2009, Who licenses out patents and why? Lessons from a business survey, OECD STI Working Paper 2009/5.

[4] OEPM, 2010, Presente y futuro de la protección de las invenciones en España, Oficina Española de Patentes y Marcas, Madrid.

[5] Giuri, P., Mariani, M., Brusoni, S., Crespi, G., Francoz, D., Gambardella, A., GarciaFontes, W., Geuna, A., Gonzales, R., Harhoff, D., Hoisl, K., 2007, Inventors and Invention Processes. Results from the PatVal-EU Survey, Research Policy, 36, 8: 110727.

[6] Hidalgo, A., 2003, Los patrones de innovación en España a través del análisis de patentes. Un análisis cualitativo en el periodo 1988-1998. Ministerio de Ciencia y Tecnología. Madrid.

[7] Arce, R., del Rey, J., Encinas D., Hidalgo, A., Malvido, G., Pérez, J.A., 2006, Patentes. Situación de las patentes en España. EOI, Escuela de Organización Industrial - OEPM Publicaciones sobre Propiedad Industrial. Madrid

[8] Hidalgo, A., 2006, Mecanismos de transferencia de tecnología y propiedad industrial entre la universidad, los organismos públicos de investigación y las empresas. Colección EOI Tecnología e Innovación. Fundación EOI. Madrid.

[9] Hidalgo, A., 2009, Analysis of the commercial use of Spanish inventions protected by patents between 1996 and 2006, Journal of Intellectual Property Rights, 14:63-69.

[10] Motohashi K., 2008, Licensing or not licensing? An empirical analysis of the strategic use of patents by Japanese firms

Research Policy, 37, 9: 1548-1555. 
[11] Kani, M., Motohashi, K., 2012, Understanding the technology market for patents: New insights from a licensing survey of Japanese firms, Research Policy, 41, 4: 226235.

[12] EPO, 2008, Applicant panel survey 2007, European Patent Office, Munich, http://www.epo.org/service-support/contact-us/surveys/patent-filings/archive.html

[13] De Rassenfosse, G., 2012, How SMEs exploit their intellectual property assets: evidence from survey data, Small Business Economics, 39, 2: 437-52.

[14] OECD, 2011, Science, Technology and Industry Scoreboard 2011, OECD, Paris.

[15] MINECO, 2011, Estrategia Estatal de Innovación, Ministerio de Economía y Competitividad, Madrid. (www.idi.mineco.gob.es) 


\section{ANNEX TABLES}

Table A1. Surveys on patenting and licensing recently implemented in Spain

\begin{tabular}{|c|c|c|c|c|c|}
\hline Survey & Objective & Year & Population of interest & $\begin{array}{l}\text { Target population } \\
\text { of firms } \\
\text { (questionnaires } \\
\text { sent) }\end{array}$ & $\begin{array}{c}\text { Responses from firms } \\
\text { (valid questionnaires } \\
\text { received) }\end{array}$ \\
\hline Hidalgo [6] & $\begin{array}{l}\text { Use of patents as a } \\
\text { source of } \\
\text { information/ } \\
\text { technological } \\
\text { surveillance }\end{array}$ & 2001 & $\begin{array}{l}\text { Spanish firms with } \\
\text { granted patents }\end{array}$ & $\begin{array}{l}546 \text { Spanish firms } \\
\text { with EPO granted } \\
\text { patents filed in } \\
1988-1998\end{array}$ & $\begin{array}{c}123 \text { responses from } \\
\text { firms } \\
(63 \% \mathrm{SMEs})\end{array}$ \\
\hline $\begin{array}{l}\text { Arce et al. } \\
\text { [7] }\end{array}$ & $\begin{array}{l}\text { Identify business } \\
\text { needs on training, } \\
\text { diffusion and } \\
\text { assistance on } \\
\text { industrial property }\end{array}$ & 2004 & $\begin{array}{l}\text { Spanish firms doing } \\
\text { R\&D continuously } \\
\text { *In addition to } \\
\text { technological centers + } \\
\text { universities + public } \\
\text { research centers }\end{array}$ & $\begin{array}{l}400 \text { Spanish firms } \\
\text { of the } 10 \text { sectors of } \\
\text { activity performing } \\
\text { more than } 80 \% \text { of } \\
\text { total R\&D activity } \\
\text { in Spain }\end{array}$ & $\begin{array}{l}113 \text { responses from } \\
\text { firms }\end{array}$ \\
\hline Hidalgo [8] & $\begin{array}{l}\text { Identify success } \\
\text { factors that } \\
\text { contribute to } \\
\text { facilitate } \\
\text { technology in } \\
\text { scientific and } \\
\text { business } \\
\text { environments }\end{array}$ & 2006 & $\begin{array}{l}\text { Spanish firms with } \\
\text { more than } 20 \\
\text { employees with R\&D } \\
\text { related activities } \\
\text { *In addition to Spanish } \\
\text { universities and public } \\
\text { research centers ) }\end{array}$ & $\begin{array}{l}\text { 5,416 firms doing } \\
\text { R\&D internally }\end{array}$ & $\begin{array}{l}250 \text { interviews to firms } \\
\text { (74\% with } 20-99 \\
\text { employees, } 14 \% \text { with } \\
100-199 \text { and } 12 \% \text { with } \\
\text { more than } 200 \\
\text { employees) }\end{array}$ \\
\hline Hidalgo [9] & $\begin{array}{l}\text { Analysis of Spanish } \\
\text { inventions } \\
\text { commercialised in } \\
\text { Spain in 1996-2006 } \\
\end{array}$ & 2007 & $\begin{array}{l}\text { Spanish firms holders } \\
\text { of OEPM patents } \\
\text { granted between } 1996 \\
\text { and } 2006\end{array}$ & $\begin{array}{c}72 \text { firms with OEPM } \\
\text { patents granted } \\
\text { between } 1996 \text { and } \\
2006\end{array}$ & 72 firms (42\% SMEs) \\
\hline $\begin{array}{l}\text { OECD/OEPM } \\
\text { survey } \\
\text { (this paper) }\end{array}$ & $\begin{array}{c}\text { Economic and } \\
\text { financial uses of } \\
\text { patents }\end{array}$ & 2008 & $\begin{array}{c}\text { Spanish firms with } \\
\text { OEPM patent } \\
\text { applications published } \\
\text { in } 2007\end{array}$ & $\begin{array}{c}679 \text { firms, with } 950 \\
\text { OEPM patent } \\
\text { applications } \\
\text { published in } 2007 .\end{array}$ & $\begin{array}{c}93 \text { firms, with } 199 \\
\text { OEPM patent } \\
\text { applications published } \\
\text { in } 2007 .\end{array}$ \\
\hline
\end{tabular}


Table A2. Distribution of responding firms by sector of activity

\begin{tabular}{|c|c|c|c|c|}
\hline \multicolumn{3}{|c|}{ National Classification of Economic Activities } & \multirow{2}{*}{\begin{tabular}{c|} 
Responses \\
69 \\
\end{tabular}} & \multirow{2}{*}{$\begin{array}{c}\% \\
\text { Total } \\
74 \% \\
\end{array}$} \\
\hline A-F & & INDUSTRY & & \\
\hline A & & Agriculture, livestock, hunting and forestry & 1 & $1 \%$ \\
\hline B & & Fishing & 0 & $0 \%$ \\
\hline $\mathbf{C}$ & & Extraction industries & 0 & $0 \%$ \\
\hline \multirow[t]{7}{*}{ D } & & Manufacturing industries & 62 & $67 \%$ \\
\hline & DG & Chemical industry & 6 & $6 \%$ \\
\hline & DJ & Metalurgy and manufacturing of metal products & 7 & $8 \%$ \\
\hline & DK & $\begin{array}{l}\text { Machinery construction and mechanical } \\
\text { equipment }\end{array}$ & 14 & $15 \%$ \\
\hline & $\mathrm{DL}$ & $\begin{array}{l}\text { Electric, electronic and optical material and } \\
\text { equipment }\end{array}$ & 14 & $15 \%$ \\
\hline & DM & Manufacturing of transport material & 7 & $8 \%$ \\
\hline & $\mathrm{DN}$ & Various manufacturing industries & 5 & $5 \%$ \\
\hline $\mathbf{E}$ & & $\begin{array}{l}\text { Production and distribution of electricity, gas } \\
\text { and water }\end{array}$ & 1 & $1 \%$ \\
\hline $\mathbf{F}$ & & Construction & 5 & $5 \%$ \\
\hline G-Q & & SERVICES & 24 & $26 \%$ \\
\hline G & & $\begin{array}{l}\text { Comerce; motor vehicles and motorcycles } \\
\text { reparation and articles of personal higiene and } \\
\text { domestic use }\end{array}$ & 5 & $5 \%$ \\
\hline $\mathbf{H}$ & & Catering & 0 & $0 \%$ \\
\hline $\mathbf{I}$ & & Transport, warehouses and communications & 2 & $2 \%$ \\
\hline $\mathbf{J}$ & & Financial intermediation & 0 & $0 \%$ \\
\hline \multirow[t]{2}{*}{ K } & & $\begin{array}{l}\text { Real estate activities and renting; business } \\
\text { services }\end{array}$ & 16 & $17 \%$ \\
\hline & KK,742 & $\begin{array}{l}\text { Engineering and architecture technical services } \\
\text { and other activities related to technical assistance }\end{array}$ & 7 & $8 \%$ \\
\hline $\mathbf{L}$ & & $\begin{array}{l}\text { Public administration, defence and social } \\
\text { security }\end{array}$ & 0 & $0 \%$ \\
\hline $\mathbf{M}$ & & Education & 0 & $0 \%$ \\
\hline $\mathbf{N}$ & & $\begin{array}{l}\text { Health related and veterinary activities, social } \\
\text { services }\end{array}$ & 0 & $0 \%$ \\
\hline $\mathbf{0}$ & & $\begin{array}{l}\text { Other social activities and services to the } \\
\text { community; personal services }\end{array}$ & 1 & $1 \%$ \\
\hline $\mathbf{P}$ & & Home activities & 0 & $0 \%$ \\
\hline \multirow[t]{2}{*}{$\mathbf{Q}$} & & Extraterritorial activities & 0 & $0 \%$ \\
\hline & & TOTAL & 93 & $100 \%$ \\
\hline
\end{tabular}

Note: This table presents the number of responses broken down by broad areas of the national classification of economic activities (Clasificación Nacional de Actividades Económicas, CNAE 93 Rev 1), and for the areas with more responses, it also includes the breakdown by subareas with more than 5 responses. 
TABLES AND FIGURES TO BE INSERTED IN THE MAIN TEXT 
Figure 1. Technological distribution of firms: target population $v$ responding firms

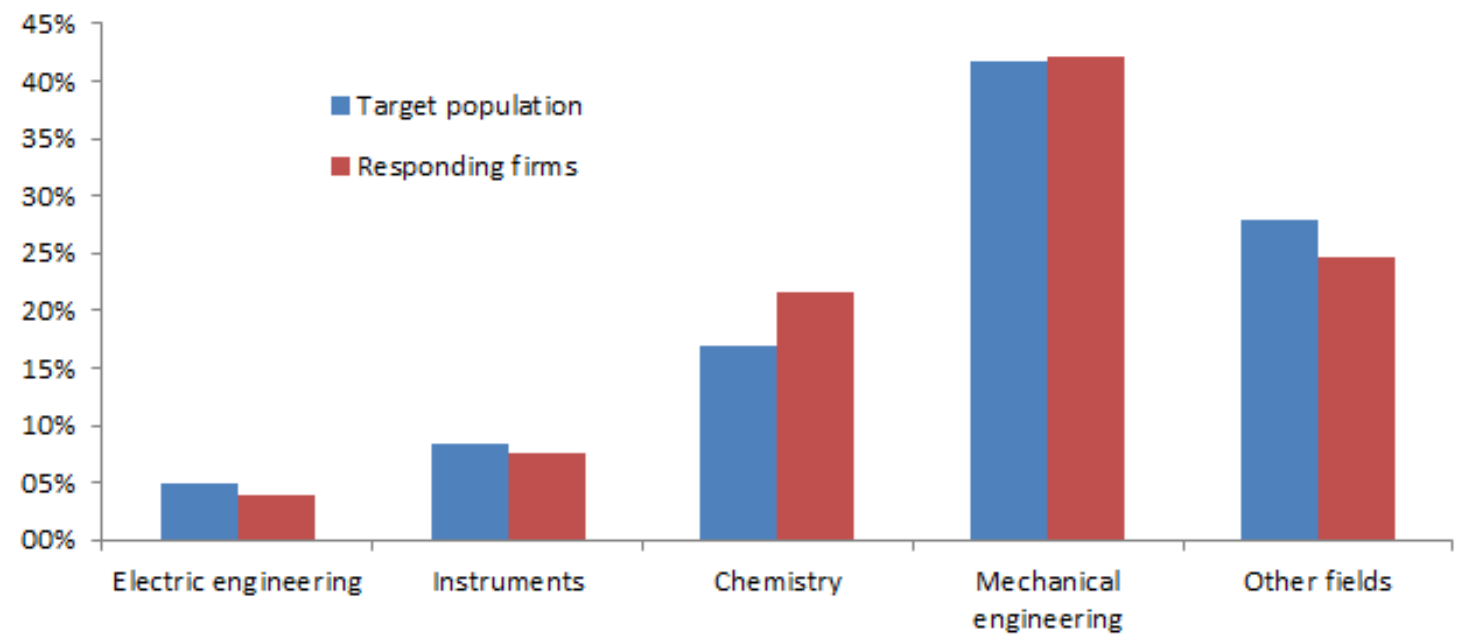

Note: Full counting. If a patent is classified in more than one technological area is counted once in each area. The five technological areas displayed in the graph are based on the correspondence between IPC clases and technological areas developed jointly by the French Patent Office, the Observatoire des Sciences et Techniques and the Fraunhofer Institute for Systems and Innovation Research, the socalled INPI/OST/FhFG classification.

Figure 2. Geographical distribution of firms: target population $v$ responding firms

A. Target population

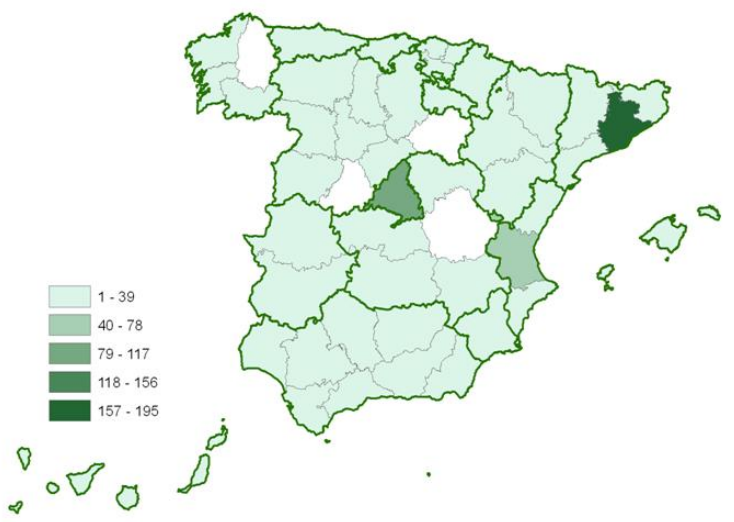

B. Responding firms

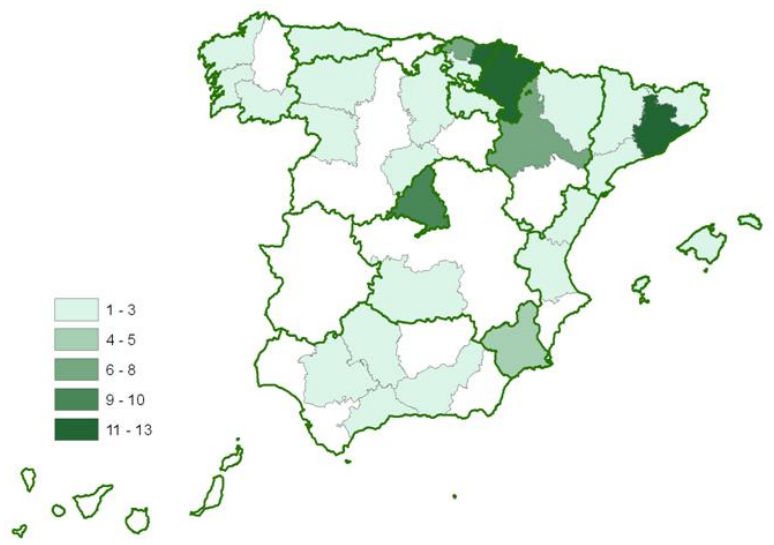


Table 1. Importance of different means to appropriate returns from innovation

\begin{tabular}{lccccc}
\hline & $\begin{array}{c}\text { Not } \\
\text { Relevant }\end{array}$ & $\begin{array}{c}\text { Low } \\
\text { importance }\end{array}$ & $\begin{array}{c}\text { Moderadately } \\
\text { important }\end{array}$ & $\begin{array}{c}\text { Very } \\
\text { important }\end{array}$ & $\begin{array}{c}\text { N } \\
\text { Patents }\end{array}$ \\
Secrecy & $8 \%$ & $8 \%$ & $28 \%$ & $62 \%$ & 92 \\
Complexity of product or process design & $9 \%$ & $17 \%$ & $36 \%$ & $39 \%$ & 89 \\
Lead time advantage & $16 \%$ & $30 \%$ & $32 \%$ & $29 \%$ & 90 \\
\hline
\end{tabular}

Table 2. Motivations to file patents

\begin{tabular}{lccccc}
\hline & $\begin{array}{c}\text { Not } \\
\text { relevant }\end{array}$ & $\begin{array}{c}\text { Low } \\
\text { importance }\end{array}$ & $\begin{array}{c}\text { Moderadately } \\
\text { Important }\end{array}$ & $\begin{array}{c}\text { Very } \\
\text { important }\end{array}$ & N \\
\hline Protection against imitation (protection) & $1 \%$ & $4 \%$ & $23 \%$ & $72 \%$ & 92 \\
Avoid litigation (defence) & $12 \%$ & $18 \%$ & $32 \%$ & $38 \%$ & 90 \\
Prevent others from patenting (blocking) & $9 \%$ & $24 \%$ & $32 \%$ & $36 \%$ & 92 \\
Gain bargaining power (bargaining) & $8 \%$ & $25 \%$ & $37 \%$ & $30 \%$ & 91 \\
Obtain additional revenues from licensing (licensing revenues) & $41 \%$ & $44 \%$ & $8 \%$ & $8 \%$ & 91 \\
Improve position in cross licensing agreements (cross licensing) & $36 \%$ & $41 \%$ & $15 \%$ & $8 \%$ & 88 \\
Improve image of reputation of the firm (reputation) & $3 \%$ & $23 \%$ & $46 \%$ & $27 \%$ & 91 \\
Obtain external funding (capital) & $30 \%$ & $35 \%$ & $30 \%$ & $5 \%$ & 91 \\
Facilitate technology exports (exports) & $23 \%$ & $23 \%$ & $33 \%$ & $20 \%$ & 90 \\
Codification of knowledge (codification of knowledge) & $26 \%$ & $43 \%$ & $23 \%$ & $8 \%$ & 90 \\
\hline
\end{tabular}

Table 3. IPR licensing contracts signed in $\mathbf{2 0 0 7}$

Share of all licensing contracts granted in 2007 by type of IPR

\begin{tabular}{lcccc}
\multicolumn{5}{c}{ Share of all licensing contracts granted in 2007 by type of IPR } \\
\hline & $\mathbf{0 \%}$ & $\begin{array}{c}\text { Less } \\
\text { than }\end{array}$ & $\begin{array}{c}\text { More } \\
\text { than }\end{array}$ & $\mathbf{N}$ \\
& & $\mathbf{5 0 \%}$ & $\mathbf{5 0 \%}$ & \\
\hline Patents & $0 \%$ & $43 \%$ & $57 \%$ & 28 \\
Trademarks & $42 \%$ & $27 \%$ & $31 \%$ & 26 \\
Know-how & $53 \%$ & $32 \%$ & $16 \%$ & 19 \\
Copyright & $81 \%$ & $13 \%$ & $6 \%$ & 16 \\
Utility models & $45 \%$ & $32 \%$ & $23 \%$ & 22 \\
\hline
\end{tabular}

Note: This table only displays responses from firms having at least one IPR licensing contract signed in 2007. The same licensing agreement can comprise different IPRs.

Table 4. Share of patents licensed

\begin{tabular}{|c|c|c|c|c|c|}
\hline & & & \multicolumn{3}{|c|}{ T-test for the equality of the means } \\
\hline & & & $\mathrm{t}$ & $d f$ & $\begin{array}{l}\text { Significance } \\
\text { (two tailed) }\end{array}$ \\
\hline Number of employees & Less than $100(20.07 \%)$ & More than 100 (4.49\%) & 2.659 & 88 & 0.009 \\
\hline Year of creation & Before 1985 (8.23\%) & After 1985 (19.77\%) & -1.950 & 88 & 0.054 \\
\hline Business group & No $(20.90 \%)$ & Yes $(7.56 \%)$ & 2.267 & 88 & 0.026 \\
\hline Business activity & Industry (16.52\%) & Services $(4.11 \%)$ & 1.805 & 88 & 0.074 \\
\hline
\end{tabular}

Note: The T-test for the equality of the means is used to test if two different groups of observations have different mean values for the same variable. The degrees of freedom (df) is the sum of responses in both groups minus 2. A 2-tailed significance less than $0.05(0.01)$ means that the probability of the two groups having the same mean for a given variable is less than $0.05(0.01)$. 
Table 5. Motives to grant patent licenses

Share of all patent licensing contracts granted in 2004-2007 corresponding to each motive

\begin{tabular}{lcccc}
\hline & $\mathbf{0 \%}$ & $\begin{array}{c}\text { Less } \\
\text { than } \\
\end{array}$ & $\begin{array}{c}\text { More } \\
\text { than }\end{array}$ & $\mathbf{N}$ \\
& & $\mathbf{5 0 \%}$ & $\mathbf{5 0 \%}$ & \\
\hline Obtain additional revenues & $63 \%$ & $9 \%$ & $29 \%$ & 35 \\
Enter into cross licensing agreements & $92 \%$ & $8 \%$ & $0 \%$ & 25 \\
Share technology with other firms (open innovation) & $86 \%$ & $7 \%$ & $7 \%$ & 28 \\
Establish a technological standard & $85 \%$ & $12 \%$ & $4 \%$ & 26 \\
Subcontract production & $82 \%$ & $11 \%$ & $7 \%$ & 28 \\
Patent infringement by third parties & $\mathbf{7 5 \%}$ & $4 \%$ & $\mathbf{2 1 \%}$ & $\mathbf{2 8}$ \\
\hline
\end{tabular}

Table 6. Barriers to grant patent licences

\begin{tabular}{|c|c|c|c|c|c|}
\hline & $\begin{array}{c}\text { Not } \\
\text { relevant }\end{array}$ & $\begin{array}{c}\text { Low } \\
\text { importance }\end{array}$ & $\begin{array}{l}\text { Moderately } \\
\text { important }\end{array}$ & $\begin{array}{c}\text { Very } \\
\text { important }\end{array}$ & $\mathbf{N}$ \\
\hline Difficult to find interested firms & $39 \%$ & $9 \%$ & $26 \%$ & $26 \%$ & 57 \\
\hline Price offered is too low & $54 \%$ & $27 \%$ & $17 \%$ & $2 \%$ & 52 \\
\hline Drafting and negotiating licensing contracts is too complex and costly & $52 \%$ & $19 \%$ & $20 \%$ & $9 \%$ & 54 \\
\hline Insufficient development of the patented technology & $48 \%$ & $23 \%$ & $15 \%$ & $13 \%$ & 52 \\
\hline
\end{tabular}

Table 7. Financial uses of patents

\begin{tabular}{lccccc}
\hline & $\begin{array}{c}\text { Not } \\
\text { relevant }\end{array}$ & $\begin{array}{c}\text { Low } \\
\text { importance }\end{array}$ & $\begin{array}{c}\text { Moderately } \\
\text { important }\end{array}$ & $\begin{array}{c}\text { Very } \\
\text { important }\end{array}$ & N \\
\hline Venture capital & $55 \%$ & $24 \%$ & $14 \%$ & $7 \%$ & 84 \\
Private investors & $51 \%$ & $23 \%$ & $17 \%$ & $10 \%$ & 84 \\
Stock market & $73 \%$ & $20 \%$ & $5 \%$ & $1 \%$ & 83 \\
Negotiate loans & $52 \%$ & $34 \%$ & $11 \%$ & $4 \%$ & 83 \\
Public funding & $20 \%$ & $22 \%$ & $45 \%$ & $13 \%$ & 86 \\
Securitisation & $49 \%$ & $27 \%$ & $18 \%$ & $6 \%$ & 78 \\
\hline
\end{tabular}

